\title{
Gronlands forhistorie
}

\section{- status over de arkaeologiske undersogelser}

Af geolog Jacob C. Yde, Aarhus Universitet.

Synergien mellem den grønlandske natur og kultur bringer fascination og ærefrygt til enhver grønlandsrejsende. Urtelier i farverigt blomsterflor, øde golde fjeldmarker, kælvende gletschere i fjordene, forbipasserende hvalers blåst, rensdyr på vandring efter føde - den frodige, korte sommer afløses af en isnende, mørk vinter. Den grønlandske natur er ubarmhjertig for enhver, som ikke kan tilpasse sig de aktuelle livsbetingelser og udnytte de arktiske ressourcer optimalt.

I dette lys skal de på hinanden følgende indvandringer af eskimoiske jægere og fangere og livsgrundlaget for nordboernes landnam ses. Kilden til forståelsen af livet på tidligere tiders bopladser er undersøgelser af de arkæologiske vidnesbyrd, som bl.a. vi geologer støder på under feltarbejde langs kysterne og i dalene. Fund af redskaber, grave og boligtomter vækker almen forundring og interesse, men indeholder også mindst to vigtige interdisciplinære perspektiver set med en geologs briller: Hvilken betydning har klimavariationer, havspejlsændringer og landhævning haft for de eskimoiske og norrøne samfund gennem den sidste del af Holocæn, og hvorfra har kulturerne fået de råmaterialer, der har været anvendt til fremstilling af stenredskaber?

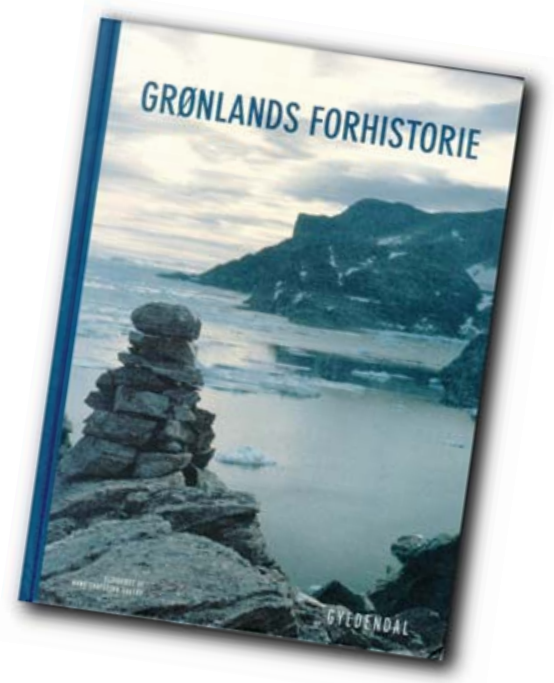

senteres kortfattet, men elegant integreret $\mathrm{i}$ fortællingen. En desværre alt for unuanceret figur sammenholder temperatursvingningerne med tidsrummet for tilstedeværelsen af de indvandrede kulturer (og enkelte af tidsrummene stemmer ikke overens med, hvad der angives i senere kapitler).

Det næste kapitel er opdelt $i$ to afsnit, der dækker de første to palæoeskimoiske kulturer, den højarktiske Independence I-kultur og den lavarktiske Saqqaqkultur, som indvandrede til Grønland fra det nordøstlige Canada. Diskussionerne af de to kulturers jagtvilkår, boligindretning, bosættelsesmønstre og redskabsproduktion er fint suppleret med mange illustrationer. Af særlig geologisk interesse er beskrivelsen af råstoffet killiaq, en silificeret skiferart, der hovedsageligt blev brudt på Nuussuaqhalvøens nordside og handlet blandt Saqqaqfolket til det øvrige Vestgrønland.

Det tredie kapitel omhandler i to afsnit de efterfølgende kulturer, Independence II udbredt i Nord- og Nordøstgrønland og tidlig Dorset udbredt i Vest- og Østgrønland. Kapitlet indledes med at betone betydningen af de kystnære polynier (en oceanografisk betegnelse for arktiske havområder, der er isfrie $i$ en længere periode end det omgivende hav) for bosættelsernes placering. Kapitlet fokuserer også på klimaforandringer særligt ved Independence II-kulturens begyndelse og afslutning. Den tidlige Dorsetkulturs foretrukne råstoffer til stenredskaber, kalcedon og killiaq, er glimrende beskrevet $\mathrm{og}$ fremvist på flotte billeder. Til gengæld synes de mange sider om redskabernes fundfordeling i boligtomterne lidt for grundig for den alment interesserede læser. 
Det fjerde kapitel beskriver den sidste palæoeskimoiske befolkning i Grønland, den sene Dorsetkultur, samt oprindelsen af de neoeskimoiske kulturer i området omkring Beringshavet. Der er en interessant diskussion af arktisk animisme, shamanisme og megalitanlæg. Den første anvendelse af metal, meteorjern fra Kap York-området, er kort omtalt, men man savner illustrationer af metalredskaber.

Nordboernes og neoeskimoiske kulturer Det femte kapitel om nordboernes livsvilkår i Grønland er spændende og velskrevet. Kapitlet afsluttes med en glimrende gennemgang af klimaudviklingens sammenhæng med nordboernes samfund, herunder affolkningen af Vester- og Østerbygden.

Det sjette kapitel omhandler Thulekulturen frem til omkring år 1900. Kulturens udvikling og de opståede forskelle mellem befolkningen i Nordøst- og Vestgrønland bevidner arkæologiens væsentlige bidrag til den grønlandske nationale identitet. Mumierne fra Qilakitsoq og de europæiske hval- fangeres tilstedeværelse er fint beskrevet.

Bogen afsluttes med et kapitel om de eskimoiske og norrøne kulturlandskaber og forvaltningen af disse i Grønland. Det sammenkæder fint Grønlands forhistorie med nutiden. Bogen er suppleret med et omfattende noteapperat og relevante referencer til i hvert fald den geologiske litteratur.

\section{Bogen vækker jalousi}

Værket Grønlands forhistorie er en effektiv introduktion til den grønlandske arkæologi og inspirerer til yderligere fordybelse. Jeg har kun få bemærkninger. Indtil kapitlet om den sene Dorsetkultur mangler mange stednavne, der nævnes i teksten, på de vejledende kort. Hvor ligger eksempelvis Saqqaqbopladsen Niivertussannguaq, Independence II-bopladsen Pullassuaq eller bopladsen Kangerlussorissunnguup Kangia fra den tidlige Dorsetkultur? Udover forfattergruppen og nogle få lokale er der næppe mange, der ved det. Resultatet er, at man som læser konstant mister den geografiske orientering og efterlades uden mulighed for at vurdere sammenhænge mellem lokaliteter. Dette kan der nemt rettes op på i fyldestgørende figurtekster til kortene. Et andet savn er palæogeografiske kort, særligt over området ved porten til Grønland over Nares Strædet. De vil være meget velkomne. Trods dette står Grønlands forhistorie som en spændende og anbefalelsesværdig milepæl over den arkæologiske forskning i Grønland.

Jeg må indrømme, at Grønlands forhistorie vækker en smule jalousi. Det er bestemt også på tide, at danske geologer og geografer, der arbejder med Grønland, samles om at formidle Grønlands geologi. Der er sket meget siden Geology of Greenland, redigeret af Escher og Watt, udkom i 1976. Det kan jo være, at vi kan bidrage til at øge arkæologernes udbytte af rejser i Grønland, som de tilsvarende har styrket vores med dette værk.

Grønlands forhistorie. H.C. Gulløv (red.) 2004. 448 sider. Udgivet af Gyldendal. Bogen koster ca. $399 \mathrm{kr}$. ISBN: 87-0201724-5

\section{Andring af giftgraensevaerdier - besparelser for det offentlige på ca. 2 mia.}

\section{Af geolog Steen Laursen, GeologiskNyt}

Ved at hæve værdierne for, hvornår en tjæreforurenet grund bliver registreret som giftgrund, kan det offentlige sparer ca. 2 mia. på kortlægning og oprensning.

Kriteriegruppen under Miljøministeriet anbefaler, at man hæver værdien for, hvornår en tjæreforurenet grund bliver registreret som giftgrund. En gennemførelse af planen vil gøre op imod 100.000 grunde i de store byer rene. Grundejerne vil dermed få lettere ved at sælge og belåne deres ejendom, og det offentlige vil sparer omkring 2 mia. kr. på kortlægning og oprensning. Embedslægerne i Københavns- og Frederiksberg Kommune betegner forureninger med de højere grænseværdier som uskadelige. Desuden har bl.a. Tyskland og Holland tilsvarende grænseværdier for tjære.

\section{Politiske kommentarer}

"Vi skal sikre et højt beskyttelsesniveau uden at skræmme danskerne og uden at bruge mange millioner på ting, der ikke er farlige", skriver miljøminister Connie Hedegaard, K, på Miljøministeriets hjemme- side. "Nu har den faglige ekspertise på området afleveret sine anbefalinger. Det betyder, at Folketingets partier har et godt grundlag for drøftelser i starten af det nye år”. Det skulle således ikke være farligere at spise jord med $3 \mathrm{mg}$ tjære $/ \mathrm{kg}$, end det er at spise en pandestegt fisk eller en grillbøf.

Partierne A, R, SF og DF er dog skeptiske. "Det er et skråplan, hvis man begynder at indrette grænseværdierne efter, hvad der er råd til og ikke efter, hvad der er sagligt og fagligt korrekt" siger Torben Hansen fra A til Berlingske Tidende. Over for samme avis er SF miljøordfører Jørgen Espersen dog ikke så afvisende "Vi er jo ikke interesseret $i$ at bruge en masse penge på at rense grunde, som ikke udgør nogen eller kun en minimal fare for miljøet. Men det vil i givet fald være et krav, at pengene så bruges på andre miljøinitiativer, fx bekæmpelse af luftforureningen i København".

\section{Kriteriegruppen}

Kriteriegruppen blev nedsat i maj 2004. Den består af repræsentanter fra Sundhedsstyrelsen, embedslægerne, Arbejdstilsynet, Fødevareministeriet, Amtsrådsforeningen, Københavns Kommune, Kommunernes Landsforening og Miljøstyrelsen.

Kriteriegruppen fik til opgave at kigge på,

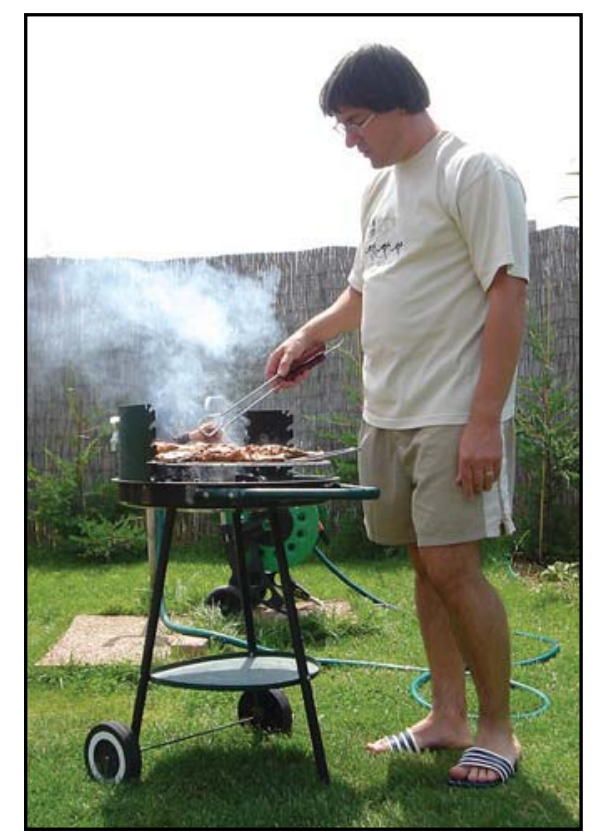

At indtagve jord med $3 \mathrm{mg}$ tjare/ $\mathrm{kg}$ eller spise en grillbøf er lige farligt. (Foto: Forfatteren)

om vi bruger de rigtige metoder, når vi fastsætter grænseværdier for vand, jord og luft, og om grundlaget for, hvornår jordforurening kortlægges, kan fastsættes mere hensigtsmæssigt - med særligt fokus på bly og tjærestoffer (PAH). 